\title{
Anadolu Lisesi Öğretmenlerinin Kaynaştırma Eğitimine İlişkin Görüşlerinin Metafor Analizi Yoluyla İncelenmesi
}

\author{
DOI: 10.26466/opus.590972
}

*

\section{Tansel Yazıcı̆ğlu*}

*Dr. Öğretim Üyesi, Nevşehir Hacı Bektaş Veli Üniversitesi, Eğitim Fakültesi, Nevşehir / Türkiye E-Posta: tanselyazicioglu@gmail.com

\author{
ORCID: 0000-0002-0946-2637.
}

\section{Öz}

$B u$ çalışmanın amacl; anadolu liselerinde görev yapan öğretmenlerin kaynaştırma eğitimine ilişkin görüşlerini metafor analizi yoluyla incelemekti. Metaforlar (mecazlar) yoluyla veri toplama yönteminin kullanıldığ bu araştırma özünde nitel bir araştırmadır. Araştırma 2018-2019 eğitim-öğretim yılında Ankara'nın Çankaya ilçesindeki üç anadolu lisesinde gerçekleştirilmiştir. Araştırma verileri bu okullarda görev yapan 100 öğretmenden toplanmıştır. Öğretmenlerin \% 15'i (15 kişi) erkek, \% 85'i (85 kişi) kadındır. Katılımcılardan "Kaynaştırma eğitimi ...... gibidir. Çünkü....." ifadesini metafor kullanarak doldurmalar istenmiştir. Öğretmenlerden elde edilen bu veriler içerik analizi veri çözümleme teknikleri kullanılarak analiz edilmiştir. Elde edilen veriler ışı̆̆ında öğretmenlerin, kaynaştırma eğitimine ilişkin 81 geçerli metafor geliştirdikleri anlaşılmıştır. Bu metaforlar 6 ana kategoride değerlendirilmiştir. Bu kategoriler farklılıkları anlama, bütünleştirme, gereksinimlerin karşılanması, okul ve toplumdaki firsatlara erişim, sosyal gelişime katkı ve uygun eğitim ortamıdır. Araştırma sonucunda, öğretmenlerin geliştirdikleri metaforlar arasında ilk sırayı farklılıkları anlama kategorisinin yer aldı ̆̆ görülmüştür. Araştırmanın sonuçlar öğretmenlerin kaynaştırma eğitiminin temel felsefesini bildiklerini fakat bunları sınıflara taşıyamadıklarını göstermiştir. Bu bilgilerin sınıflara taşınabilmesi için onlara uygun destek hizmetlerinin sağlanması gerekmektedir.

Anahtar Kelimeler: Kaynaştırma eğitimi, metafor, özel gereksinimli birey 


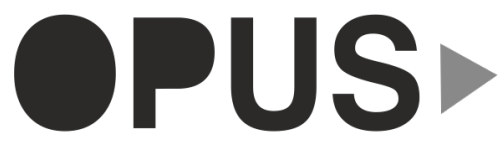

Uluslararası Toplum Araştırmaları Dergisi International Journal of Society Researches
E-ISSN : 2528-9535

YIl Year: 9

Cilt Volume: 14

Sayı Issue :20

Aralık December 2019

Makalenin Gelis Tarihi Received Date: 11/07/2019

Makalenin Kabul Tarihi Accepted Date: 21/11/2019

\title{
Investigation of Anatolian High School Teachers' Views on Inclusive Education through Metaphor Analysis
}

\begin{abstract}
In this study, it is aimed to examine the views of teachers who work in anatolian high schools about inclusive through metaphor analysis. This is a qualitative research. The research was carried out in three anatolian high schools in Çankaya district of Ankara in 2018-2019 academic year. The research data were collected from 100 teachers who work in these schools. 15\% of the teachers (15 people) are male and $85 \%$ (85 people) are female. Participants were asked to complete the sentences in writing such as "Inclusive education is...looks like because... with metaphors they choose. The data were analyzed using content analysis techniques. In the light of the data obtained, it was understood that teachers developed 81 valid metaphors related to inclusive education. These metaphors were grouped under 6 main categories. These metaphors are understanding differences, integrating, meeting needs, accessing opportunities in schools and communities, contributing to social development, and an appropriate educational environment. As a result of the research, it is seen that the first place among the metaphors developed by the teachers is the category of understanding differences. The results of this study show that teachers know the basic philosophy of inclusive education but can not carry them to the classrooms. However, in order to transfer this information to the classes, appropriate support services should be provided for them.
\end{abstract}

Keywords: Inclusive, metaphor, with special need individual 


\section{Giriş}

Günümüzde, özel gereksinimli çocukların eğitimine ilişkin en tartışmalı konulardan birisi de kaynaştırma eğitimidir (Farrel, 2010; Kauffman ve Badar, 2014; Slee, 2011). Sharma'ya (2015) göre kaynaştırma eğitimi konusunda dünyada iki farklı bakış açısı vardır. Birincisi, büyük ölçüde, gelişmiş ülkelerin ihtiyaç ve koşullarından kaynaklanan bakış açısı, ikincisi gelişmekte olan ülkelerde geçerli olan ihtiyaç ve koşullardan kaynaklanan bakış açısıdır. Bugün dünyada bulunan "yetersizliği olan birey" sayısı bir milyardan fazladır ve bunların \% 10'u çoğunlukla gelişmekte olan ülkelerde yaşayan çocuklardır.

Kaynaştırma teorileri ve kaynaştırma eğitimi hem gelişmiş ülkelerde, hem de gelişmekte olan ülkelerde önemli bir özel eğitim politikası ve uygulamasıdır (Artiles, Kozleski ve Waitoller, 201; Singal ve Muthukrishna, 2014). Kaynaştırma eğitimi, genel olarak toplumsal kabul, farklılık ve çeşitliliğin benimsenmesini, insan haklarının dikkate alınmasını, sosyal adalet ve eşitlik konularının yanı sıra sosyal bir engellilik modeli ve sosyo-politik bir eğitim modelini içerir. Ayrıca okul dönüşüm sürecini ve çocukların eğitim ve öğretime erişimine odaklanmayı da kapsar (Kozleski, Artiles ve Waitoller 2011; Loreman, Deppeler ve Harvey, 2011; Mitchell, 2005; Slee, 2011; Smith, 2010; Topping, 2012). Salend (1998) tarafından kaynaştırma eğitimi, tüm öğrencilerin birbirlerinin farklılıklarını öğrendikleri ve bu farklılıklara saygı gösterdikleri bir yaklaşımdır. Okullar ile kurumlar bu gereksinimleri karşılamayı esas alırlar. Kırcaali-İftar'a (1992) göre kaynaştırma, özel gereksinimli öğrenciye gerekli destek özel eğitim hizmetlerinin sağlanması koşuluyla, tam zamanlı ya da bazı durumlarda yarı zamanlı olacak şekilde kendisi için en az kısıtlayıcı eğitim ortamı olarak kabul edilen genel eğitim sınıflarında eğitim sunulmasıdır. Yasal tanımında ise kaynaştırma, özel eğitim ihtiyacı olan bireylerin her tür ve kademede diğer bireylerle karşılıklı etkileşim içinde bulunmalarını ve eğitim amaçlarını en üst düzeyde gerçekleştirmelerini sağlamak amaciyla bu bireylere destek eğitim hizmetleri de sunularak akranlarıla birlikte tam zamanlı ya da özel eğitim sınıflarında yarı zamanlı olarak verilen eğitimdir (Milli Eğitim Bakanlığı, [MEB], 2018). 
Ülkemizde, çeyrek asırdan fazla (36 yıl) uygulanan kaynaştırma eğitimine ilişkin çok sayıda araştırma yapılmış, genel eğitim okullarında görev yapan öğretmenlerin, yöneticilerin müfettişlerin görüşleri ile öğretmen adaylarının, özel gereksinimli öğrenci aileleri ile özel gereksinimli olmayan öğrenci ailelerinin, özel gereksinimli olan ve olmayan öğrencilerin kaynaştırma eğitimine ilişkin görüşleri belirlenmiştir. Diğer taraftan bazı araştırmacılar öğretmen adaylarının kaynaştırma eğitimi, kaynaştırma öğretmeni ve kaynaştırma öğrencilerine ilişkin algılarını (Altıntaş, Baykan, Kahraman ve Altıntaş, 2015), okul öncesi öğretmen adaylarının kaynaştırma öğrencisi kavramına ilişkin algılarını (Talas, 2017) metaforlar aracılığıyla incelemişlerdir. Yapılan bu araştırmaların sonuçlarında öğretmen adaylarının kaynaştırma eğitimine, kaynaştırma yoluyla eğitim veren öğretmene ve kaynaştırma yoluyla eğitim alan öğrenciye ilişkin farklı metaforlar oluşturdukları görülmüştür. Altıntaş, Baykan, Kahraman ve Altıntaş (2015) tarafından yapılan araştırmanın sonuçları kaynaştırma eğitimi, kaynaştırma öğretmeni ve kaynaştırma öğrencisi kavramlarının daha çok çiçekli bitkilere benzetildiğini göstermiştir. Araştırma sonuçları ayrıca öğretmen adaylarının cinsiyet ve öğrenim durumunda farklılık olmadığını, mezun olunan lise düzeyinde farklılıkların olduğunu ortaya koymuştur. Talas (2017) tarafından yapılan araştırmanın sonuçlarında ise katılımcılar 74 metafor üretmişlerdir. Bu metaforların 52'si olumlu, 22'si ise olumsuz bulunmuştur.

Kaynaştırma programları ülkemizde her tür ve kademedeki okul veya kurumda uygulanmaktadır. Özellikle 30 Mart 2014 tarihinde Türkiye Büyük Millet Meclisi'nde (TBMM) kabul edilen, 4+4+4 eğitim yasası olarak bilinen 6287 sayılı "İlköğretim ve Eğitim Kanunu ile Bazı Kanunlarda Değişiklik Yapılmasına Dair Kanun" ile, sekiz yıl olan zorunlu eğitim 12 yıla çıarılarak 12 yıllık süre, dört yıl süreli ilkokul, dört yıl süreli ortaokul ve dört yıl süreli lise olarak düzenlenmiştir. Bu düzenleme kaynaştırma öğrencilerini de etkilemiş, çok sayıda kaynaştırma öğrencisi ortaöğretim kurumlarında öğrenimlerini sürdürmeye başlamıştır. Bu durum ortaöğretim kurumlarında görev yapan öğretmenlerin kaynaştırma eğitimi konusundaki bilgi ve deneyimleri ile kaynaştırma eğitimine bakış açılarının önemini arttırmıştır. Nitekim alanyazında öğretmenlerin eğitim deneyimlerinin, özel eğitime ilişkin 
almış oldukları eğitimlerin, daha once bir kaynaştırma öğrencisiyle çalışıp çalışmamalarının ve yaşlarının kaynaştırma eğitimine ilişkin tutumlarını etkilediği ifade edilmektedir (Avramidis ve Norwich, 2002; Avramidis, Baylis ve Burden, 2010). Başarılı bir kaynaştırma eğitimi için öncelikle başta okul müdürü olmak üzere tüm okul çalışanları, özel gereksinimli öğrencilere karşı, kabul edici ve destekleyici bir tutum sergilemelidirler. Çünkü özel gereksinimli çocuklar ve aileleri daha okula kayıt aşamasından başlayarak müdür, müdür yardımcısı, rehberlik öğretmenleri, diğer öğretmenler, memurlar ve diğer okul personeli ile etkileşim halindedir (Kargın, 2010, s. 64). Dolayısıyla ortaöğretim kurumlarında görev yapan öğretmenlerin kaynaştırma eğitimine ilişkin algılarının önemli olduğu düşünülmektedir. Ülkemizde ortaöğretim kurumları, ortaokul veya imam-hatip ortaokulu üzerine öğrenim süresi dört yıl olan yatılı ve/veya gündüzlü olarak eğitim ve öğretim veren kurumlardır. Bu kurumlar; fen liseleri, sosyal bilimler liseleri, anadolu liseleri, güzel sanatlar liseleri ve spor liseleri, anadolu imam hatip liseleri, mesleki ve teknik anadolu liseleri, mesleki ve teknik eğitim merkezleri, çok programlı anadolu liseleri, özel eğitim meslek liseleri ile mesleki eğitim merkezlerinden oluşmaktadır (MEB, 2017). Bu kurumlardan biri olan anadolu liselerinde görev yapan öğretmenlerin kaynaştırma eğitimine ilişkin algılarını metaforlar aracılığıyla ölçen bir araştırmaya rastlanmamıştır. Ayrıca metaforlar dişında, lise düzeyinde kaynaştırma bilgisi ve tutumu gibi değişkenleri ele alan çalışmaların çok sınırlı olması, yapılan çalışmaların daha çok ilkokul ve ortaokul düzeyinde yapılması bu araştırmanın önemini daha da arttırmaktadır. Bu araştırmanın amacı anadolu liselerinde görev yapan öğretmenlerin kaynaştırma eğitimine ilişkin algılarını ortaya koymaktır. Bu amaç doğrultusunda aşağıdaki araştırma sorularına yanıt aranmıştır:

1. Anadolu liselerinde görev yapan öğretmenlerin kaynaştırma eğitimine ilişkin sahip oldukları metaforlar nelerdir?

2. Bu metaforlar ortak özellikleri açısından hangi kavramsal kategoriler altında toplanabilir?

3. Bu metaforlar anadolu lisesi öğretmenlerinin kaynaştırma eğitimi anlayışıyla ilgili neler söylemektedir? 


\section{Yöntem}

\section{Araştırma Modeli}

Metaforlar (mecazlar) yoluyla veri toplama yönteminin kullanıldığı bu araştırma nitel araştırma yöntemiyle desenlenmiştir. Morgan'a (1986) göre metaforlar bir durumu belirleme ve bir süreci hızlandırma veya iyileştirme amacıyla kullanılır. Yıldırım ve Şimşek'e (2013) göre metaforların nitel bir veri toplama yöntemi olarak kullanılması daha çok betimlemleyici rolüne karşılık gelmektedir. Arnett'e (1999) göre metafor bir alg1 aracıdır. Metaforlar olayların oluşmasında ve işleyiş biçiminde düşüncelerimize yön veren ve ayrıca kontrol eden en güçlü zihinsel araçlardan biridir (Saban, 2004). Metaforlar (benzetmeler, eğretilemeler, istiareler, mecazlar) olayların oluşumu ve işleyişi hakkında düşüncelerimizi yapılandıran, yönlendiren ve kontrol eden en güçlü zihinsel araçlardan biridir (Örücü, 2012). Yıldırım ve Şimşek'e (2013) göre metaforların farklı sözcüklerden oluşması ayrıştırılmasını kolaylaştırır ve bu durum araştırmacı için bir problem teşkil etmez. Ayrıca metaforların benzerlik ve farklılıklarını tema başlıkları altında toplamak kolaydır. Metaforların bir özelliği de çalışılan konu, olgu, olay ve durumlar hakkında sağlam ve zengin resim sunması, görsel bir imaj sağlamasıdır.

\section{Katılımcılar}

Araştırmaya 2018-2019 eğitim öğretim yılında Ankara ili Çankaya ilçesi Çayyolu Bölgesindeki üç anadolu lisesinde görev yapan (Birinci okul 35, ikinci okul 32, üçüncü okul 33 öğretmen) 100 öğretmen katılmıştır. Öğretmenlerin \% 15'i (15 kişi) erkek, \% 85'i (85 kişi) kadındır. Öğretmenlerin \% 14'ü Türk Dili ve Edebiyatı (14 kişi), \%13'ü Matematik (13 kişi), \%13'ü İngilizce (13 kişi), \%10’u Tarih (10 kişi), \%10'u Biyoloji (10 kişi) \% 8'i Fizik (8 kişi), \%6'sı Kimya (6 kişi), \% 5'i Coğrafya (5 kişi), \%5'i Beden Eğitimi (5 kişi), \%4'ü Din Kültürü ve Ahlak Bilgisi (4 kişi), \% 4'ü Bilişim Teknolojileri (4 kişi), \% 3'ü Görsel Sanatlar (3kişi), \% 3’ü Müzik (3kişi), \% 2'si (2 kişi) Felsefe öğretmenidir. Öğretmenlerin \% 65'i (65) 21 yıl ve üzeri, \% 25'i (25) 31 yıl ve üzeri ve \% 10'u (10) ise 11-20 ylllık mesleki deneyime sahiptir. 


\section{Veri Toplama Araci}

Öncelikle araştırmaya katılan öğretmenlere metaforun ne anlama geldiği bir kaç örnekle açıklanarak öğretmenlerin "Kaynaştırma Eğitimi" sözcügüne ilişkin sahip oldukları metaforları ortaya çıkarmaları amaçlanmıştır. Sonrasında kendilerine verilen form üzerindeki "Kaynaştırma Eğitimi" ...... gibidir, çünkü.......boş cümlesini doldurmaları istenmiştir. Bunun yanında örneklem grubunun betimlenmesi için katılımclardan görev yaptıkları okulun türünü, meslekteki kıdemlerini, cinsiyet ve alan bilgilerini içeren bireysel bilgi formunu doldurmaları istenmiştir.

\section{Verilerin Toplanması}

Araştırmanın verileri öğretmenlerin verilen çalışma formunu yazılı olarak doldurmaları şeklinde elde edilmiştir. Çalışma formunda; öğretmenlere, araştırmanın amacı ve bilimsel amaçla kullanılacağına ilişkin gerekli bilgilendirmenin yapıldığı ve örnek metafor örneğinin verildiği bir yönerge bölümü oluşturulmuştur. Öğretmenler formları 20-60 dakika içinde doldurmuşlardır.

\section{Verilerin Analizi}

Öğretmenlerin el yazıları ile doldurdukları formlar, araştırmacı tarafından kodlanarak bilgisayar ortamında yazılı hale getirilmiştir. Veriler içerik analizi tekniği ile analiz edilmiştir. İçerik analizi yapılırken Saban'ın (2009) kullandığı aşamalar takip edilmiştir. Bu aşamalar sırasıyla adlandırma aşaması, eleme ve arıtma aşaması, derleme ve kategori geliştirme aşaması ve geçerlilik ve güvenirliliğin sağlanması aşamasıdır.

Adlandırma aşaması:Araştırmada öğretmenlerin tamamına ulaşılmış, öğretmenlerin her birine numaralar verilmiş ve 1. öğretmen (Ö-1) şeklinde gösterilmiştir. Öğretmenlere verilen formlar teslim edilme durumlarına göre numaralandırılmış, numaralanan her sayfadaki metafor verilen numaraya göre kodlanmıştır (Örneğin: Ö1: zincir, Ö2: terazi gibi). Tespit edilen metaforlar ilk önce verilen numaraya göre sıralanmıştır. 
Eleme ve arıtma aşaması: Kodlama işlemi 100 öğretmen formu üzerinde gerçekleştirilmiştir. Ancak öğretmenlerden 19'unun tutarlı bir açıklamaya sahip olmayan metafor imgeler kullandıkları için 19 form araştırmanın dışına çıkarılarak ayıklama yapılmıştır. Dolayısıyla kodlama işlemi 81 öğretmen üzerinde gerçekleştirilmiştir. Metaforlar tekrar alfabetik sıraya göre dizilmiş, metafor ifadesi seçilerek örnek metafor listesi oluşturulmuştur.

Derleme ve kategori geliştirme aşaması: $\mathrm{Bu}$ aşamada, öğretmenler tarafından oluşturulan metaforlardan geçerli olan 81 metafor ortak özellikleri bakımından incelenmiştir. Bu incelemede öncelikle öğretmenlerin kaynaştırma eğitimine yönelik olumlu ve olumsuz metaforları tespit edilmiştir. Daha sonra "öğretmenler tarafından üretilen her metafor imgesi; metaforun konusu (1), metaforun kaynağ1 (2) ve metaforun konusu ile kaynağı arasındaki ilişkisi (3) bakımlarından analiz edilmiştir. $\mathrm{Bu}$ ilişki doğrultusunda incelenen metaforlar ortak özellikler açısından altı kategoride toplanmıştır.

Geçerlik ve güvenirliği sağlama aşaması: Nitel araştırmada güvenilirliği arttırmak için araştırmacıların bazı önlemler almaları önerilmektedir. Silverman'a (2000) göre araştırmacının araştırmasının dış güvenilirliğini izlediği aşamaları ayrıntılı ve açı bir biçimde rapor ederek; iç güvenirliliğini ise araştırma sonuçlarını kendi tercih ve yönelimleri dışında tutarak ve okuyucuyu ikna ederek sağlayabilir. Ayrıca araştırma sonucu rapor edilirken bulguların bir bölümünün orijinalliği bozulmaksızın verilmesi araştırmanın iç güvenilirliğini önemli bir şekilde yükseltecektir. Yıldırım ve Şimşek'e (2013) göre de araştırma konusunda genel bilgiye sahip ve nitel araştırma yöntemleri konusunda uzmanlaşmış kişilerden, yapılan araştırmayı çeşitli boyutlarıyla incelemesinin istenmesi inandırıcılık konusunda alınabilecek önlemlerden bir diğeridir. $\mathrm{Bu}$ araştırmada metaforların kategorileştirilmesi sürecinde özel eğitim alanında çalışan iki öğretim üyesinin görüşüne başvurulmuştur. Araştırmacı ve uzmanların incelemesi sonunda altı kategori üzerinde görüş ayrılığ1 olduğu görülmüştür. Miles ve Huberman (1994,s.64) tarafından verilen aşağıdaki güvenirlik formülü araştırmacı ve özel eğitim alanında görev yapan bir öğretim üyesi tarafından kullanılarak 
görüş birliği ve görüş ayrılığının, araştırmanın güvenirliğine etkisi hesaplanmıştır. Güvenirlik = Görüş Birliği x 100/ Görüş Birliği + Görüşs Ayrilığı Uygulanan formül sonucunda güvenirlilik \% 0.90 olarak hesaplanmıştır. Görüş ayrılığına düşülen altı kategori üzerinde görüşüne başvurulan uzmanlarla tartışılmış ve görüş birliği sağlanmıştır.

\section{Bulgular}

Araştırmaya katılan öğretmenler toplam 81 adet metafor üretmişlerdir. Bu metaforlar şunlardır: Zincir (4), terazi (1), güneş (2), pazıl (3), zincir halkası (2), kedi (1), ilk yardım çantası (1), çiçek bahçesi (3), takviye vitesi (1), sebze çorbası (2), anne (1), ayna (5), halat ip (1), suya düşen damla (1), tren (1), dal (3), gökkuşağ1 (7), merdiven (1), üzüm bağ1 (2), yolculuk (1), para (2), fidan (3), bulut (1), 1şık (1), tahtaravelli (1), basamak (1), göl (1), mandala (1), ilkyardım (2), cankurtaran (2), uçan balon (1), bağ (2), su (2), orkestra (1), sanat (1), çiçek tarlası (2), salata (1), toprak (1), nefes (1), örgü (1), yemek (1), başak tarlası (1), rehber (1), yapıştırıcı (2), resim (1), telefon (2), hayat damarı (2).

Öğretmenlerin üretmiş oldukları bu metaforlar incelendikten sonra, metaforlardan alt kategoriler oluşturulmuştur. Öğretmenlerin kaynaştırma eğitimine ilişkin ürettikleri metaforlardan oluşturulan alt kategoriler gruplandırılarak Tablo 1'de verilmiştir.

\section{Tablo 1. Kaynaştırma Eğitimine Ilişkin Geliştirilen Metaforlar}

\begin{tabular}{ll}
\hline Kategoriler & Metaforlar \\
\hline Farklılıkları anlama & $\begin{array}{l}\text { gökkuşağı (7), çiçek bahçesi (3), sebze çorbası (2), } \\
\text { ççek tarlası (2), salata (1), ayna (5), mandala (1), } \\
\text { orkestra (1), bulut (1) }\end{array}$ \\
\hline Bütünleştirme & $\begin{array}{l}\text { zincir (4), suya düşen damla (1), pazıl (3), zincir } \\
\text { halkası (2), dal (3), tahtaravelli (1), sanat (1), resim } \\
(1), \text { yapıştırıcı (2) }\end{array}$ \\
\hline Gereksinimlerin karşılanması & $\begin{array}{l}\text { cankurtaran (2), yemek (1), hayat damarı (2), } \\
\text { ilkyardım (2), güneş, (2) su (2), nefes (1), ilk yardım } \\
\text { çantası (1), halat ip (1), fidan (3), 1şık (1), göl (1), } \\
\text { rehber (1), }\end{array}$ \\
\hline Okul ve toplumdaki fırsatlara erişim & merdiven (1), terazi (1), yolculuk (1), para (2) \\
\hline Sosyal gelişime katkı & anne (1), bağ (2), üzüm bağ (2), telefon (2), takviye \\
& vitesi (1), tren (1), basamak (1), örgü (1), \\
\hline Uygun eğitim ortamı & uçan balon (1), toprak (1), başak tarlası (1), kedi (1) \\
\hline
\end{tabular}


Tablo 1 incelendiğinde öğretmenlerin kaynaştırma eğitimini en fazla farklılıkları anlama $(n=23)$ ve gereksinimlerin karşılanması $(n=20)$ olarak gördükleri anlaşılmaktadır. Bunları sırayla bütünleştirme $(\mathrm{n}=18)$, sosyal gelişime katkı $(n=11)$, okul ve toplumdaki fırsatlara erişim $(n=5)$ ve uygun eğitim ortamı $(n=4)$ kategorileri izlemektedir.

Öğretmenlerin oluşturdukları metaforların nedenleri için formdaki "çünkü" açıklamalarına bakılmış ve kategoriler bu açıklamalar esas alınarak oluşturulmuştur. Kategorilere ait alıntı ve açıklamalar aşağıda sırayla verilmiştir.

\section{Kategori 1. Farklılıklarn anlama}

Bu kategori altındaki metaforlar incelendiğinde çoğunun farklı türlerden oluşan bir topluluğu konu alan metaforlar olduğu anlaşılmaktadır. Bunlar; gökkuşağı (7), çiçek bahçesi (3), sebze çorbası (2), çiçek tarlası (2), salata (1) ve orkestra (1) dir. Bu kategori altında ayrıca farklılıkları yansıtan ayna (5), mandala (1) ve bulut (1) gibi mateforlar yer almıştır. Aşağıda, araştırmaya katılan öğretmenlerin kaynaştırma eğitiminin farklılıkları anlama kategorisine vurgu yapan metaforları niçin tercih ettiklerine ilişkin bazı alıntılara yer verilmiştir.

- Ö-19: Kaynaştırma eğitimi "gökkuşağı" gibidir. Çünkü yedi renkten biri olmazsa eksik kalır.

- Ö-39: Kaynaştırma eğitimi "gökkuşă̆ı" gibidir. Çünkü her renk bir duyguya denk. Özel gereksinimli olan çocukların akranlarıyla birlikte olması hem birey olarak gelişimleri, hem de toplumda bir yer edinebilmelerinde önemli. Gökkuşağ renklerle güzel.

- Ö-38: Kaynaştırma eğitimi "çiçek bahçesi” gibidir. Çünkü bahçede her çiçek farklıdır. Farklılıklar güzeldir.

- Ö-11: Kaynaştırma eğitimi "sebze çorbası" gibidir. Çünkü bir malzeme olmazsa eksik olur.

- Ö-54: Kaynaştırma eğitimi "çiçek tarlası" gibidir. Çünkü her türlü çiçek birbirini tanır. Diğer çocuklar da hayatta çok farklı çiçeklerin, hayatların olabileceğini görür. Dünyanın sadece kendi etrafında dönmediğini anlarlar. Hep birlikte tarlaya dünyaya ait olduklarını yaşayarak farkederler. 
- Ö-52: Kaynaştırma eğitimi “orkestra” gibidir. Çünkü tıpkı bir orkestra gibi farklı aletler vardır ve bunu yönetmek öğretmenin işidir. Öğretmen de bir orkestra şefidir.

- Ö-14: Kaynaştırma eğitimi "ayna” gibidir. Çünkü hem mesleki hem de insani özelliklerimizi farketmediğimizde bir bakış açısına ayna tutarlar.

- Ö-37: Kaynaştırma eğitimi "mandala" gibidir. Çünkü sabır ve itina ile seçtiğimiz renk uyumu sayesinde muhteşem bir eser çıkarabiliriz. Yani mental ve bedensel yetersizliği olan çocukların duygu durumlarını dikkate alarak sınıf ortamında sabır ve itina ile alıştırmak gerekir.

- Ö-55: Kaynaştırma eğitimi "salata" gibidir. Çünkü salatadaki her bir bitkinin farklı bir özelliği ve tadı vardır. Ancak farklı olan bitkiler salata tabağına girdiklerinde hepsinin karışımından farklı bir tad çıkar. Ne kadar farklı bitki varsa tad o kadar değişik olur.

- Ö-30: Kaynaştırma eğitimi "bulut" gibidir. Çünkü gökyüzü bazen pırıl pırıl, bazen kara, bazen açıtır. Bu farklılıklar giyim ve kuşamımızı, seyehatlerimizi etkiler. Kaynaştırma eğitimi de tıpkı farklı bulutlar gibi bizim eğitim anlayışımızı etkiler.

\section{Kategori 2. Bütünleştirme}

$\mathrm{Bu}$ kategori altındaki metaforlar incelendiğinde bütünün parçalarını vurgulayan ve bu birlikteliğin önemini konu alan metaforlar olduğu anlaşılmaktadır. Bunlar; zincir (4), suya düşen damla (1), pazıl (3), zincir halkası (2), dal (3), tahtaravelli (1), yapıştırıcı (2), sanat (1) ve resim (1) dir. Aşağıda, öğretmenlerin kaynaştırma eğitiminin bütünleştirme kategorisine vurgu yapan metaforları niçin tercih ettiklerine ilişkin alıntılara yer verilmiştir.

- Ö-77: Kaynaştırma eğitimi "pazıl" gibidir. Çünkü eksik olan parçaların bir araya getirilmesini sağlar. Kişide eksik olan birim ne ise kaynaştırma eğitiminde onu tamamlamak hedeflenmelidir. Böylece kişiyi diğerinden ayıran fark ya da eksiklik kapatılmış, ortaya bir bütün çıkmıştır. Bu eğitim verilirken de uzman kişilerin doğru noktalara eğilerek bireydeki eksik olan yerleri adeta bir pazıl gibi tamamlaması gerekmektedir. 
- Ö-1: Kaynaştırma eğitimi "zincir" gibidir. Çünkü toplumda herkesi birbirine bağlar.

- Ö-12: Kaynaştırma eğitimi "zincir" gibidir. Çünkü bir halka olmazsa eksik olur.

- Ö-5: Kaynaştırma eğitimi "zincir halkası" gibidir. Çünkü hepsi bir arada bir bütünün oluşturur.

- Ö-46: Kaynaştırma eğitimi “dal” gibidir. Çünkü ağacın dallarına ihtiyaç vardır.

- Ö-16: Kaynaştırma eğitimi "suya düşen damla" gibidir. Çünkü bu damla tek başına anlam ifade etmez. Karıştığ 1 suyla anlam kazanır. Kaynaştırma eğitimi de böyledir. Bu eğitimi alan kişi su damlası gibi diğerleriyle kaynaşır. Böylece yanlızlıktan, ötekileşmekten kurtulur.

- Ö-34: Kaynaştırma eğitimi “tahtaravalli” gibidir. Çünkü tek kişi kalkarsa oyun bozulur.

- Ö-53: Kaynaştırma eğitimi "sanat" gibidir. Çünkü duygusal olmaları, kendilerine hesapsız ifade etmeleri, samimiyetleri, niyetleri aşk gibi sanatın her dalında kameranın önünde arkasında hep olmalıdır. Aramızda, yaşamımızda olmazsa olmazlarımızdır.

- Ö-46: Kaynaştırma eğitimi "resim" gibidir. Çünkü resim renkleriyle, tueliyle, fırçasıyla, boyasıyla bir bütündür. Bir de ressamı vardır. Resimdeki eksiklik hemen göze çarpar.

- Ö-80: Kaynaştırma eğitimi "yapıştırıcı" gibidir. Çünkü bu onların en doğal hakkıdır. Kaynaştırma eğitimi birleştiricidir, bütünleştiricidir. Özel eğitime ihtiyacı olan bireylerin akranlarıyla sosyalleştiği, bir şeyler payşlaştığı bir ortamdır. Diğer öğrenciler de bu öğrencilere yardımcı olur, destek olur böylece toplumsal bütünlük sağlanır.

\section{Kategori 3. Gereksinimlerin karşılanması}

$\mathrm{Bu}$ kategori altındaki metaforlar incelendiğinde araştırmaya katılan öğretmenlerin kaynaştırma eğitimini özel gereksinimli öğrencilerin temel ihtiyacı ve bu ihtiyacın karşılanmasında önemli bir araç olarak gördükleri anlaşılmaktadır. Bunlar; cankurtaran (2), yemek (1), hayat damarı (2), ilkyardım (2), güneş, (2) su (2), nefes (1), ilk yardım çantası (1), halat ip (1), fidan (3), 1şık (1), göl (1) ve rehber (1) dir. Aşağıda öğretmenlerin kaynaştırma eğitiminin gereksinimlerin karşılanmasını 
vurgulayan metaforların niçin tercih edildiklerine ilişkin alıntılara yer verilmiştir.

- Ö-42: Kaynaştırma eğitimi “cankurtaran” gibidir. Çünkü bu eğitimle öğrenci değer gördüğünü anlar ve farkındalığı artar.

- Ö-41: Kaynaştırma eğitimi “ilk yardım” gibidir. Çünkü özel gereksinimli öğrencileri hayata bağlar.

- Ö-48: Kaynaştırma eğitimi "su" gibidir. Çünkü özel gereksinimli olan çocukların da diğer çocuklar gibi suya ihtiyacı vardır. Susuz kalan çiçek de solar. Bu çocuklarımızın da yaşam kaynağımız olan su gibi kaynaştırma eğitimine ihtiyacı vardır.

- Ö-51: Kaynaştırma eğitimi "güneş" gibidir. Çünkü bizim çocuklarımız çiçek gibidir. Güneş ışı̆̆ı olmazsa solarlar, yaşayamazlar.

- Ö-31: Kaynaştırma eğitimi "ışık” gibidir. Çünkü özel eğitime ihtiyacı olan çocukları aydınlatır.

- Ö-15: Kaynaştırma eğitimi "halat ip" gibidir. Çünkü ihtiyaç halinde kullanılır. Diğer zamanlarda kenarda bekler. Kaynaştırma eğitimi de özel eğitime ihtiyaç duyan çocuklar için ihtiyaçtır.

- Ö-36: Kaynaştırma eğitimi "göl” gibidir. Çünkü kenarında yaşayan insanların bazı ihtiyaçlarını karşılar. Örneğin balık tutma, dinlenme, sulama, hatta tuz gibi.

- Ö-57: Kaynaştırma eğitimi "nefes” gibidir. Çünkü özel gereksinimli olan çocuklara hayat verir.

- Ö-65: Kaynaştırma eğitimi "yemek" gibidir. Çünkü eksik olursa tadı olmaz.

- Ö-68: Kaynaştırma eğitimi "rehber" gibidir. Çünkü özel gereksinimli çocukların eğitimlerinin karşılanmasında kılavuzluk eder, yol gösterir. Belirli bir planı, programı vardır.

- Ö-79: Kaynaştırma eğitimi "ilkyardım çantası" gibidir. Çünkü özel gereksinimli çocukların akranlarıyla sağlıklı iletişim kurabilmesini, yaşamda çevresiyle sağlıklı iletişim kurabilmesini sağlar.

- Ö-58: Kaynaştırma eğitimi "hayat damarı" gibidir. Çünkü bu çocuklar için eğitim çok çok daha önemli. Hayatları gerçekten çok zor. Onun için kaynaştırma eğitimi büyük fırsat. 
- Ö-29: Kaynaştırma eğitimi "fidan" gibidir. Çünkü bu çocuklarla ilgilenirseniz meyvelerini alırsınız. Fidan nasıl suya ihtiyaç duyuyorsa bu çocuklar da kaynaştırma eğitimine ihtiyaç duyuyorlar.

\section{Kategori 4. Okul ve toplumdaki firsatlara erişim}

$\mathrm{Bu}$ kategori altındaki metaforlar incelendiğinde araştırmaya katılan öğretmenlerin kaynaştırma eğitimini özel gereksinimli bireyler için önemli bir fırsat olarak gördükleri anlaşılmaktadır. Bu metaforlar; merdiven (1), terazi (1), yolculuk (1) ve para (2) dır. Aşağıda, bu metaforların öğretmenler tarafından niçin tercih edildiklerine ilişkin alıntılara aşağıda verilmiştir.

- Ö-21: Kaynaştırma eğitimi "merdiven" gibidir. Çünkü adım adım ihtiyacı olan kişiler kendilerine akranları arasında yer bulur. Zaman içerisinde onlar gibi olmaya başlar.

- Ö-2: Kaynaştırma eğitimi "terazi” gibidir. Çünkü kişileri ayırmadan, ayrıştırmadan, sunulan haklara eşit (öğretmen, okul, okul olanakları) ve adil biçimde kullanmalarını sağlar.

- Ö-24: Kaynaştırma eğitimi "yolculuk” gibidir. Çünkü beraber çıkılan bu yolda herkes birbirinden bir şeyler öğrenir.

- Ö-26: Kaynaştırma eğitimi "para" gibidir. Çünkü verdiğinin karşılığını alırsın. Kaynaştırma eğitimiyle ne verirseniz karşılığında da onu alırsiniz.

\section{Kategori 5. Sosyal gelişime katkı}

$\mathrm{Bu}$ kategori altındaki metaforlar incelendiğinde araştırmaya katılan öğretmenlerin kaynaştırma eğitiminin özel gereksinimli bireylerin sosyal gelişimlerini olumlu olarak etkilediğini düşündükleri anlaşılmaktadır. Bu düşüncelerini gösteren metaforlar; anne (1), bağ (2), üzüm bağ (2), telefon (2), takviye vitesi (1), tren (1), basamak (1) ve örgü (1) dür. Aşağıda, öğretmenlerin kaynaştırma eğitiminin sosyal gelişime katkısınına vurgu yapan metaforları niçin tercih ettiklerine ilişkin bazı alıntılara yer verilmiştir.

- Ö-13: Kaynaştırma eğitimi "anne” gibidir. Çünkü anne kadar özen, samimiyet ve sicaklık ister. 
- Ö-50: Kaynaştırma eğitimi "bağ (kuvvetli)" gibidir. Çünkü hem sevgi bağı, hem eğitim anlamında tüm öğrenciler arasında eşit kuvvette çekilen bir bağ gibidir. Kaynaştırma öğrencisi "soy metal" gibi kimse ile bir etkileşim halinde olmazsa fiziksel, psikolojik ve akademik anlamda olumsuz bir durum söz konusu olacaktır.

- Ö-47: Kaynaştırma eğitimi “üzüm bağı” gibidir. Çünkü bu eğitimi alan bireyler diğer bireylerle kaynaşır, birleşir, toplum içinde kabul görürler. Aralarında sıkı bir bağ oluşur.

- Ö-17: Kaynaştırma eğitimi "tren" gibidir. Çünkü öğrencilerin bir birlerini ileri doğru çekmelerini sağlar. Dolayısıyla sosyal bağ oluşur.

- Ö-10: Kaynaştırma eğitimi "takviye vitesi" gibidir. Çünkü zorlanan çocuklar akranlarıyla aynı yokuşu birlikte çıkabilirler. Zorlukları paylaşırlar. Yoldaş olurlar.

- Ö-64: Kaynaştırma eğitimi "örgü" gibidir. Çünkü örgü ne kadar çoğalır ve sıklaşırsa atılan bağ da o kadar güçlü olur. Eğitimde de kaynaşma kolay olur.

- Ö-69: Kaynaştırma eğitimi "telefon" gibidir. Çünkü paylaşımın, sosyal ilişkilerin gelişmesinde önemli rol oynar. Telefonsuz bir sosyal hayat nasıl olmuyorsa, kaynaştırmasız bir okul da sosyal olmaz.

- Ö-35: Kaynaştırma eğitimi "basamak" gibidir. Çünkü özel gereksinimli çocuklar basamak basamak diğer çocuklarla iletişim kurarak yükselirler.

\section{Kategori 6. Uygun eğitim ortamı}

$\mathrm{Bu}$ kategori altındaki metaforlar incelendiğinde araştırmaya katılan öğretmenlerin kaynaştırma eğitimi için gerekli olan koşullara vurgu yaptıkları anlaşılmaktadır. Bu vurgularını gösteren metaforlar uçan balon (1), toprak (1), başak tarlası (1) ve kedi (1) dir. Aşağıda, öğretmenlerin bu vurguyu niçin yaptıklarına dair alıntılara yer verilmiştir.

- Ö-45: Kaynaştırma eğitimi "uçan balon" gibidir. Çünkü özel eğitim alan öğrenci uygun eğitim çevresindeyse sosyalleşir, gelişir. Uygun bir eğitim ortamında değilse tıpkı balon gibi söner, yalnızlaşır.

- Ö-56: Kaynaştırma eğitimi "toprak" gibidir. Çünkü doğada her toprağın bir işlevi vardır. Ancak önemli olan uygun topraktır. Özel 
eğitime ihtiyacı olan çocuklar için de uygun okullar, uygun programlar olmalıdır.

- Ö-66: Kaynaştırma eğitimi "başak tarlası" gibidir. Çünkü başak iyi bir tarlada mahsul verir. Tarla ne kadar iyi sürülür, ne kadar havalandırılır ve temizlenirse başak da o kadar iyi olur. Özel eğitime ihtiyacı olan çocuklar için de durum böyledir.

- Ö-7: Kaynaştırma eğitimi "kedi" gibidir. Çünkü kediler kendilerine uygun yerleri severler ve bu yerlerde sakin olurlar. Bir kedi nereyi sıcak, güvenli bulursa orayı benimser. Kaynaştırma eğitimi de böyle bir ortam ister.

\section{Tartışma, Sonuç ve Öneriler}

Anadolu liselerinde görev yapan öğretmenlerin kaynaştırma eğitimine ilişkin görüşlerinin metaforlar yoluyla incelendiği bu araştırmada oluşturulan metaforlar altı kategoride toplanmıştır. $\mathrm{Bu}$ metaforlar farklılıkları anlama, bütünleştirme, gereksinimlerin karşılanması, okul ve toplumdaki fırsatlara erişim, sosyal gelişime katkı ve uygun eğitim ortamidir.

Farklılıkları anlama kategorisi öğretmenlerin en fazla metafor $(n=23)$ geliştirdikleri kategori olmuştur. Bu sonuç Salend'in (1998) kaynaştırma eğitimi tanımı ile birebir örtüşen sonuçtur. Salend (1998) kaynaştırma eğitimini, tüm öğrencilerin farklılıkları öğrendikleri ve birbirlerine sayg1 gösterdikleri bir süreç olarak tanımlamaktadır. Araştırmanın bu bulgusu öğretmenlerin kaynaştırma eğitimini farklılık temelinde algıladıklarını göstermektedir. Ancak her ne kadar farklılıklar temelinde bir algılama olsa da aslında tüm çocukların benzer öğrenme aşamalarından geçtiği ve kaynaştırma eğitimine devam eden öğrencilerin sadece ufak birtakım ek düzenlemelere ihtiyaç duydukları unutulmamalıdır. Nitekim Landberg, Kruger ve Nell'e (2005) kaynaştırma eğitiminin bireylerin farklılık, işbirliği ve öğrenmeye ilişkin değerleri, inançları ve tutumlarında farklılığı içeren bir çoğulculuğu simgelediğini ifade etmektedirler.

Araştırmanın bütünleştirmeye ilişkin kategorisi değerlendirildiğinde bazı öğretmenlerin kaynaştırma eğitiminin dal, zincir, pazıl gibi metaforlarla bütünleştirici özelliğine vurgu yaptıkları görülmektedir. Bu vurgu aslında kaynaştırma eğitiminin tanımını akla getirmektedir. Alanyazında 
kaynaştırmanın tanımının genel olarak, özel gereksinimli öğrencilerin, özel gereksinimli olmayan akranlarıyla birlikte, en az kısıtlayıcı eğitim ortamı ilkesi gereğince genel eğitim sınıflarında, öğretmen ve öğrencilerin gereksinimlerine uygun destek hizmetlerin sağlanması koşuluyla eğitim almaları şeklinde yapıldığı görülmektedir (Lewis ve Doorlag, 1999; McCoy, 1995; Osborne ve Dimattia, 1994; Salend, 1998). Tanımdan da anlaşılacağı üzere, kaynaştırma eğitimi özel gereksinimli öğrenciler ile özel gereksinimli olmayan öğrencilerin belirlenen bir sinıfta bir araya getirildikleri bir uygulama değildir. Dolayısıyla öğretmenlerin bütünleştirmeye yönelik geliştirdikleri metaforların kaynaştırma eğitiminin tanımıyla doğrudan örtüşmediği anlaşılmaktadır. Diğer yandan Milli Eğitim Bakanlığı Özel Eğitim Hizmetleri Yönetmeliği'nin (2018) tanımlar ve kısaltmalar başlıklı 4. maddesinde kaynaştırma eğitimi, "Kaynaştırma/bütünleştirme yoluyla eğitim uygulamaları, “Özel eğitim ihtiyacı olan bireylerin her tür ve kademede diğer bireylerle karşılıklı etkileşim içinde bulunmalarını ve eğitim amaçlarını en üst düzeyde gerçekleştirmelerini sağlamak amacıyla bu bireylere destek eğitim hizmetleri de sunularak akranlarıyla birlikte tam zamanlı ya da özel eğitim sınıflarında yarı zamanlı olarak verilen eğitim" şeklinde ifade edilmiştir. Görüldügü gibi kaynaştırma eğitimi belirli ilke ve koşulları olan bir eğitim modelidir.

Araştırmanın gereksinimlerin karşılanmasına ilişkin kategorisi değerlendirildiğinde, öğretmenlerin kaynaştırma eğitimini özel gereksinimli öğrencilerin temel ihtiyacı olarak algıladıkları görülmektedir. Bu durum aslında öğretmenlerin özel gereksinimli öğrencilerin eğitim haklarını vurguladıklarını göstermektedir. Çünkü metaforlar incelendiğinde su, nefes, hayat damarı, yemek gibi birey için yaşamsal değeri olan metaforlar üretilmiştir. Öğretmenlerin temel insan haklarından birisi olan eğitim hakkına vurgu yapmaları memnuniyet vericidir. Nitekim kaynaştırma eğitimi herkese eşit düzeyde eğitim olanağı sağlanan (Mitchell, 2005), her öğrencinin hak ve menfaatlerini içeren (Jenkinson, 1997) ve tüm öğrencilerin gereksinimlerini karşılamayı hedefleyen okul ve sosyal kurumlar oluşturmayı amaçlayan bir eğitim yaklaşımı olarak (Salend, 1998) ifade edilmektedir. Ayrıca Birleşmiş Milletler Eğitim, Bilim ve Kültür Kurumu (UNESCO) tarafından kabul edilen "Eğitimde Ayrımcılı̆̆a Karşı Sözleşme" de (1960) herhangi bir kişi ya da grubun, herhangi bir 
tür ya da düzeyde eğitim görmekten yoksun bırakılamayacağı belirtilmiştir. Yine Salamanca Bildirisi'nin (2004) 2. Maddesinde “Özel eğitim gereksinimi olanlar, normal okullara devam edebilmeli ve bu okullar onlarm ihtiyaçların karşılayabilecek, "çocuğu merkez alan" eğitim sistemi içinde yetiştirilmelidir." ifadesine yer verilmiştir. Dolayısıla uluslararası sözleşmelerle güvence altına alınan eğitim hakkının bu araştırmanın sonuçlarında da elde edilmiş olmasının kaynaştırma eğitimi açısından umut verici olduğu söylenebilir.

Araştırmanın okul ve toplumdaki fırsatlara erişim kategorisine ilişkin bulgusu, kaynaştırma eğitiminin özel gereksinimli öğrenciler açısından önemli bir fırsat olarak görüldügünü ortaya koymuştur. Nitekim bazı öğretmenler kaynaştırma eğitimini merdiven, terazi, yolculuk ve para gibi metaforlara benzetmişlerdir. Bu metaforların tercih edilme nedenleri değerlendirildiğinde özel gereksinimli öğrencilerin eğitime erişimlerinde kaynaştırma eğitiminin önemli bir araç olarak görüldüğü anlaşılmaktadır. Bu durum kaynaştırma eğitiminin alanyazındaki bir çok tanımıyla örtüşmektedir. Örneğin Rudd (2002) kaynaştırmanın, çocukların tamamını kapsayan, okul ve toplumdaki firsatların tamamına sadece sinıfta verilen eğitimle erişilebilen bir uygulamadan daha kapsamlı bir felsefe içerdiğini belirtmektedir. Lindsay (2007) ise kaynaştırmanın önemli bir eğitim planı olduğunu vurgulamakta, bu planın özel gereksinimli çocukların eğitim olanaklarınının arttırılmasında önemli rol oynadığını ifade etmektedir. Lindsay'e (2007) göre kaynaştırma eğitiminin desteklenmesindeki iki önemli nedenden ilki özel gereksinimli öğrenciler için kaynaştırmanın daha etkili olması, diğeri ise bu öğrencilerin okullarda kaynaştırma yoluyla eğitim hakkına sahip olmalarıdır.

Araştırma bulguları öğretmenlerin kaynaştırma eğitimini sosyal gelişime katkı sağlayan bir uygulama olarak algıladıklarını göstermiştir. Araştırmanın bu bulgusu kaynaştırma eğitiminin yararlarını destekler niteliktedir. Nitekim, özel gereksinimli öğrencilerin ayrıştırılmış ortamlarla karşılaştırıldığında, kaynaştırma ortamlarında daha fazla sosyal etkileşime geçtikleri ifade edilmektedir (Kwon, Elicker ve Kontos, 2011). Buysse, Goldman ve Skinner'a (2002) göre kaynaştırma ortamları arkadaşlıkların, sosyal ve iletişim becerilerinin gelişimi açısından daha fazla fırsatlar sunmaktadır. Fryxell ve Kennedy (1995) yaptıkları araştırmada genel eğitim sınıfına devam eden ağır derecede yetersizliği olan öğren- 
cilerin sosyal ilişkileri ile özel eğitim sınıflarına devam eden ağır derecede yetersizliği olan öğrencilerin sosyal ilişkilerini karşılaştırmışlardır. Araştırma bulguları, genel eğitim sınıfına devam eden ağır derecede yetersizliği olan öğrencilerin, özel eğitim sınıflarına devam eden ve akranlarına göre daha fazla sosyal destek sağlanan ağır derece yetersizliği olan öğrencilerden daha fazla sosyal etkileşim gösterdiklerini ortaya koymuştur. Benzer bir araştırmada Kennedy, Shukla ve Fryxell (1997) tarafından yapılmıştır. Araştırmada kaynaştırma sınıflarına devam eden ağır yetersizliği olan ortaokul öğrencileri ile özel eğitim sınıflarına devam eden ağır yetersizliği olan ortaokul öğrencilerin sosyal ilişkileri karşılaştırılmıştır. Araştırma bulguları kaynaştırma sınıflarına devam eden ağır yetersizliği olan ortaokul öğrencilerinin yetersizliği olmayan sınıf arkadaşları ile daha fazla etkileşime geçtiklerini, daha fazla ve daha uzun süreli sosyal iletişim kurduklarını ortaya koymuştur.

Araştırmanın son bulgusu uygun eğitim ortamının gerekliliğine ilişkin bulgusudur. Öğretmenlerin bazıları kaynaştırma eğitiminin koşullarını vurgulayan metaforlar geliştirmişlerdir. Öğretmenlerin geliştirdikleri bu metaforlar özel gereksinimli öğrencilerin eğitimlerinde önemli olan en az kısıtlayıcı ortam ilkesini akla getirmektedir. En az kısıtlayıcı eğitim ortamında özel gereksinimli öğrenciler mümkün olduğunca özel gereksinimli olmayan akranlarıyla aynı eğitim ortamını paylaşırlar (Mastropieri ve Scruggs, 2000) ve bu ortam destek eğitim hizmetleri sağlanması koşuluyla tam zamanlı ya da yarı zamanlı olarak oluşturulabilir (Batu ve Kırcaali-İftar, 2005). Dolayısıyla eğitim ortamının kaynaştırma öğrencilerine uygun hale getirilmesi kaynaştırma eğitiminin ön koşullarından birisidir. Ayrıca alanyazında başarılı bir kaynaştırma için özel gereksinimli öğrenciye sistemli ve kapsamlı bir öğretim programının sunulması, tüm öğrencilerin, tüm öğretmenlerin, özel gereksinimli öğrenci aileleri ile özel gereksinimli olmayan öğrenci ailelerinin ve yöneticilerin hazırlandığı ve işbirliği içinde çalıştığı bir eğitim ortamının oluşturulması gerektiği ifade edilmektedir (Allen \& Cowdery, 2015; Aral, 2011; Batu, Çolak ve Odluyurt, 2013; Guralnick, 2001; Özdemir ve Ahmetoğlu, 2012). Eğitim ortamları personel, fiziki mekan, donanım, öğrenme araç ve gereçleri, özel düzenlemeler gibi alt öğelerden oluşan dinamik bir yapıdır (Aydın, 2000; Uludağ ve Odacı, 
2002). Bu yapının uygunluğu kaynaştırma eğitiminin başarısında önemli bir koşulun gerçekleşmesi anlamına gelmektedir. Bu araştırmanın sonuçlarında da öğretmenler bu koşula dikkat çekmişlerdir.

Sonuç olarak bu araştırma anadolu liselerinde görev yapan öğretmenlerin kaynaştırma eğitimine bakış açılarını yansıtmıştır. Araştırmanın bulguları bir bütün olarak değerlendirildiğinde, öğretmenlerin kaynaştırma eğitimini daha çok farklılıkları anlama olarak algıladıkları, ayrıca kaynaştırma eğitimini özel gereksinimli öğrencilerin eğitime erişimlerinde önemli bir araç olarak gördükleri anlaşılmaktadır. Öğretmenler ayrıca kaynaştırma eğitiminin öğrencilerin sosyal gelişimleri üzerindeki etkilerine vurgu yaparken, aynı zamanda da kaynaştırma eğitiminin gerekliliklerine dikkat çekmişlerdir. Bu araştırmanın sonuçları aslında öğretmenlerin kaynaştırma eğitiminin temel felsefesini bildiklerini fakat bunları sınıflara taşıyamadıklarını göstermiştir. Ancak bu bilgilerin sınıflara taşınabilmesi için onlara uygun destek hizmetlerin sağlanması gerekmektedir.

$\mathrm{Bu}$ araştırma sonucunda elde edilen bulgular ışığında ortaöğretim kurumlarının eğitim ortamları kaynaştırma eğitimine uygun hale getirilebilir. Metafor kullanımı ve analizi yoluyla yapılacak çalışmalarla daha fazla sayıda öğretmenin kaynaştırma eğitimine ilişkin inançları ve bunların sebepleri araştırılabilir. 


\section{EXTENDED ABSTRACT}

\section{Investigation of Anatolian High School Teachers' Views on Inclusive Education through Metaphor Analysis \\ *}

Tansel Yazıcıŏglu

Nevşehir Hacı Bektaş-ı Veli University

Today, one of the most controversial issues regarding the education of children with special needs is inclusive education (Farrel, 2010; Kauffman and Badar, 2014a; Slee, 2011). According to Sharma (2015), there are two different perspectives on inclusion education in the world. The first is the point of view that arises largely from the needs and conditions of developed countries, and the second is the point of view that arises from the needs and conditions that apply in developing countries. Today, the number of disabled people in the world is more than one billion, which is $10 \%$ of the children in developing countries. Inclusive theories and inclusive education is an important special education policy and practice in both developed and developing countries. (Artiles, Kozleski and Waitoller, 201; Singal and Muthukrishna, 2014). Inclusive education generally includes adoption of social acceptance, diversity and diversity, consideration of human rights, social justice and equality as well as a social disability model and a socio-political education model. Inclusive programs are implemented in schools and institutions of all types and levels in our country. In particular, on March 30, 2014 Turkey Grand National Assembly (Parliament) adopted $4+4+4$, which is known as the Education Law No. 6287 "Law on Amending Some Laws Primary Education Law" and the eight-year compulsory education by subtracting 12 years The 12-year period was organized as four-year primary school, four-year secondary school and four-year high school. This regulation also affected the inclusive students by allowing a large number of those students to continue their education in secondary schools. This situation has increased the importance of the knowledge and experience of the teachers working in secondary education institutions on inclusion education and 
their perspectives on inclusion education. As a matter of fact, it is stated in the literature that the educational experiences of the teachers, the education they have received about special education, whether they have worked with a mainstream student and their ages affect their attitudes towards mainstream education (Avramidis and Norwich, 2002; Avramidis, Baylis and Burden, 2010).

For successful inclusion education all school employees, especially the school principal, should adopt an accepting and supportive attitude towards students with special needs. Because children with special needs and their families interact with principals, deputy principals, guidance teachers, other teachers, civil servants and other school personnel starting from the school enrollment stage (Kargin, 2010, p. 64). Therefore, it is considered that the perceptions of the teachers working in secondary education institutions about the mainstreaming education are important. There is no study that measures the perceptions of the teachers working in Anatolian high schools, which are one of these institutions, on the inclusion education through metaphors. This increases the importance of the research. The aim of this study is to reveal the perceptions of the teachers working in Anatolian high schools about inclusive education.

This is a qualitative research, using metaphors (metaphors). According to Morgan (1986), metaphors are used to determine a situation and to speed up or improve a process. According to Yıldırım and Şimşek (2013), the use of metaphors as a qualitative data collection method corresponds to the descriptive role. One hundred teachers participated in the study in 2018-2019 academic year who work in three Anatolian high schools located in Çayyolu region of Çankaya district of Ankara province. Fifteen percent of the teachers (15 people) are male and 85\% (85 people) are female. Teachers were asked to complete the sentences in writing such as "Inclusive education is....looks like because.... with metaphors they choose. The data were analyzed using content analysis techniques. In the light of the data obtained, it was understood that teachers developed 81 valid metaphors related to inclusive education. These metaphors were grouped under 6 main categories. These metaphors are understanding differences, integrating, meeting needs, accessing opportunities in schools and communities, contributing to social development, and an appropriate educational environment. 
Understanding differences is the category in which teachers developed the most metaphors $(\mathrm{n}=23)$. This result is consistent with Salend's (1998) definition of inclusive education. According to Salend (1998), inclusion education is that all students learn about each other's differences and respect each other.

When the integration category of the research is evaluated, it is seen that some teachers emphasize the integrative feature of inclusive education especially with metaphors such as branch, chain and pazıl. This emphasis actually brings to mind the definition of inclusive education. When the common aspects of inclusive and definitions are brought together, it is seen that inclusive is defined as the provision of support services that teachers and students need in the general education classrooms in accordance with the principle of least restrictive environment, together with their peers with no special needs (Lewis and Lewis Doorlag, 1999; McCoy, 1995; Osborne and Dimattia, 1994; Salend, 1998).

When the category of the study regarding the meeting of the needs is evaluated, it is seen that teachers perceive inclusive education as the basic need of students with special needs. This situation shows that teachers emphasize the educational rights of students with special needs. Because when the metaphors are examined, metaphors that produce vital needs for the individual such as water, breath, life vessel, and food are produced.

As a result, this study reflects the perspectives of teachers who work in Anatolian high schools in inclusive education. When the findings of the study are evaluated as a whole, it is understood that teachers perceive inclusion education as more understanding of differences, and they also see inclusion education as an important tool in accessing education to students with special needs. The teachers also emphasize the effects of inclusive education on students' social development, as well as the necessities of inclusive education.

\section{Kaynakça / References}

Allen, K. E. ve Cowdery, G. E. (2015). The exceptional child: Inclusion in early childhood education (8th ed.). Stamford, CT: Cencage Learning. 
Altıntaş, G., Baykan, Ö., Kahraman, E. ve Altıntaş, S. U. (2015). Öğretmen adaylarının kaynaştırma eğitimi, kaynaştırma öğretmeni ve kaynaştırma öğrencilerine ilişkin metaforik algıları. Ĕ̆itim ve Öğretim Araştırmaları Dergisi, 4(1), 15.

Aral, N. (2011). Okul öncesi eğitimde kaynaştırma. İstanbul: Morpa Yayınları.

Arnett, R. C. (1999). Metaphorical guidance: Administration as building and renovation. Journal of Educational Administration, 37(1), 80-89.

Artiles, A. J., Kozleski, E. B. ve Waitoller, F. R. (2011) Inclusive education:Cambridge. MA: Harvard University Press.

Avramidis, E. ve Norwich, B. (2002). Teachers' attitudes towards integration/inclusion: A rewiew of literature. Europen Journal.of Special Needs Education, 17(2), 129-147.

Avramidis, E., Bayliss, P. ve Burden, R. (2010). A survey into mainstraem teachers' attitudes towards the inclusion of children with special educational needs in ordinary school in local education authority. Educational Psychology, 20(2), 203-211.

Aydın, A. (2000). Sinıf yönetimi. Ankara: Anı Yayıncilık.

Batu, S., Çolak, A. ve Odluyurt, S. (2013). Özel gereksinimli çocukların kaynaştırılması. Ankara: Vize Yayıncilık.

Batu, S. ve Kırcaali, İ. (2005). Kaynaştırma. Ankara: Kök Yayıncılık

Buysse, V., Golman, B. D.and Skinner, M. L. (2002). Setting effects on friendship formation among young children with and without disabilities. Exceptional Children, 68, 503-517.

Farrell, M. (2010). Debating special education. London: Routledge.

Fryxell, D. ve Kennedy, C. (1995). Placement along the continuum of services and its impact on students' social relationships. Journal of the Association for Persons with Severe Handicaps, 20, 259-269.

Guralnick, M.J. (2001). Early childhood inclusion: Focus on change. Baltimore: Brookes.

Jenkinson, J.C. (1997). Mainstream or special? Educating students with disabilities. New York: Routledge Publishing.

Kauffman, J. M. ve Badar, J. (2014) Instruction, not inclusion, should be the central issue in special education: An alternative view from the USA, Journal of International Special Needs Education, 17 (1), 13-20. 
Kennedy, C. H., Shukla, S. ve Fryxell, D. (1997). Comparing the effects of educational placement on the social relationships of intermediate school students with severe disabilities. Exceptional Children, 64, 3147.

Kırcaali-İftar, G. ( 1992). Özel eğitimde kaynaştırma. Eğitim ve Bilim, 16, 4550.

Kozleski, E. B., Artiles, A. J. ve Waitoller, F. R. (2011) Introduction: equity in inclusive education: historical trajectories and theoretical commitments. In (A. J. Artiles, E. B. Kozleski and F. R. Waitoller eds) Inclusive Education. Cambridge, MA: Harvard University Press.

Kwon, K. A., Elicker, J. ve Kontos, S. (2011). Social IEP objectives, teacher talk, and peer interaction in inclusive and segregated preschool setting. Early Childhood Inclusion Journal, 1-11.

Landberg, E., Kruger, D. ve Nell, N. (2005). Addressing bariers to learning. Pretoria: Van Shcaik Publishing.

Lewis, R., B. ve Doorlag, H., D. (1999). Teaching special education students in general education classrooms. New York: Merril, Prentice Hall.

Lindsay, G. (2007). Educational psychology and the effectiveness of inclusive education/mainstreaming. British Journal of Educational Psychology, 77(1), 1-24.

Loreman, T., Deppeler, J. ve Harvey, D. (2011) Inclusive education: Supporting diversity in the classroom (2nd edition). Crows Nest, Australia: Allen \& Unwin.

Mastropieri, M. ve Scruggs, T. (2000). The inclusive classroom: Strategies for effective instruction. Columbus, $\mathrm{OH}$ : Merrill.

McCoy, K. M. (1995). Teaching special learners in the general education classroom. Denver: Love Publishing.

Miles, M. B. ve Huberman, A. M (1994). Qualitative data analysis: An expanded sourcebook. California: Sage Publications.

Ortaöğretim Kurumları Yönetmeliği. (2017). Resmi Gazete, (No:30182).

Özel Eğitim Hizmetleri Yönetmeliği. (2018). Resmi Gazete, (No:30471).

Mitchell, D. (2005) Contextualizing inclusive education. London: Routledge.

Morgan, G. (1986). Images of organization. Newbury Park, CA: Sage

Osborne, A., G. ve Dimattia, P. (1994). The least restrictive environment mandate: Legal implications. Exceptional Children, 61(1), 6-14. 
Örücü, D. (2012). Primary school teachers' metaphorical perspective stowards classroom and classroom management: A comparative case study. Elementary Education Online, 11(2), 342-352, 2012.

Özdemir, H. ve Ahmetoğlu, E. (2012). Okul öncesi öğretmenlerinin yaşları ve mesleki deneyimleri açısından kaynaştırma uygulamalarına ilişkin görüşlerinin incelenmesi. Journal of Educational and Instructional Studies in the World, 2(1), 68-74.

Rudd, F. (2002). Grasping the promise of inclusion. 26, ERIC database ED471855

Saban, A. (2004). Giriş düzeyindeki sınıf öğretmeni adaylarının 'öğretmen' kavramına ilişkin ileri sürdükleri metaforlar. Türk Eğitim Bilimleri Dergisi, 2(2), 131-155.

Salend, S. J. (1998). Effective mainstreaming creating inclusive classrooms. New York: Merril, Prentice Hall.

Sharma, A. (2015). Perspectives on inclusive education with reference to united nations. Universal Journal of Educational Research, 3(5), 317-321.

Silverman, D. (2000). Doing qualitative research: A practical handbook. London: Sage.

Singal, N. ve Muthukrishna, N. (2014) Introduction: education, childhood and disability in countries of the south re-positioning the debates.Childhood, 21 (3), 293-307.

Slee, R. (2011). The irregular school: exclusion, schooling and inclusive education. London: Routledge.

Smith, P. (2010) Whatever happened to inclusion? The place of students with intellectual disabilities in general education classrooms. In(P. Smith ed.) Whatever Happened to Inclusion? NewYork: Peter Lang.

Talas, S. (2017). Okul öncesi öğretmen adaylarının "kaynaştırma öğrencisi" kavramına ilişkin algilarının metafor analizi yoluyla incelenmesi. Journal of International Management, Educational and Economics Perspectives, 5(2), 34-44.

Topping, K. (2012) 'Conceptions of inclusion: widening ideas. In (C. Boyle and K. Topping eds) What Works in Inclusion? Maidenhead: Open University Press.

Uludağ, Z. ve Odacı, H. (2002). Eğitim öğretim faaliyetlerinde fiziksel mekan. Milli Eğitim Dergisi, s. 153-154.

Yıldırım, A., ve Şimşek, H. (2013). Sosyal bilimlerde nitel araştırma yöntemleri. Ankara: Seçkin Yayıncılık. 


\section{Kaynakça Bilgisi / Citation Information}

Yazıcıoğlu, T.(2019).Anadolu lisesi öğretmenlerinin kaynaştırma eğitimine ilişkin görüşlerinin metafor analizi yoluyla incelenmesi. OPUS-Uluslararası Toplum Araştırmaları Dergisi, 14(20), 394420.DOI: 10.26466/opus.590972 